\title{
Reimplantace aortální chlopně
}

\author{
Jiří Novosad', Karel Lukeš1, Martin Urban', Piotr Branny ${ }^{1}$, Renáta Nevřalová2, Libor Škňouřil ${ }^{2}$ \\ 'Oddělení kardiochirurgie, Kardiocentrum, Nemocnice Podlesí, a. s., Trinec, \\ ${ }^{2}$ Oddělení kardiologie, Kardiocentrum, Nemocnice Podlesí, a. s., Trinec, Česká republika
}

Novosad J, Lukeš K, Urban M, et al. Reimplantace aortální chlopně. Cor Vasa 2010;52:594-596.

Cíl: Metodu reimplantace aortální chlopně (dle Davida I) jsme zavedli na našem pracovišti v roce 2005. Používáme ji u pacientů s patologií aortálního kořene a současně s regurgitací aortální chlopně. Cílem je tedy zhodnocení funkce aortální chlopně v průběhu 1-5 let od operace.

Metodika: Operovali jsme celkem sedm pacientů (čtyři muži, tři ženy), průměrného věku 56,4 roku (43-72 let). Všichni pacienti měli dilatovaný bulbus aorty, vzestupnou aortu a insuficienci aortální chlopně. Cípy neměli patologicky postiženy. Ani jeden pacient neměl Marfanův syndrom či disekci vzestupné aorty a vždy šlo o plánovaný výkon.

Výsledky: Průměrné krevní ztráty byly $1155 \pm 548 \mathrm{ml}$, žádný pacient nebyl revidován pro krvácení. Šest pacientů bylo propuštěno domů v průběhu 6-11 dní, jedna pacientka po 26 dnech (dlouhodobá umělá plicní ventilace). Po 12 měsících mělo šest pacientů při kontrolním echokardiografickém vyšetření aortální insuficienci 0.-1. stupně, jeden pacient aortální insuficienci 2. stupně. Po pěti letech má závažnou insuficienci aortální chlopně pouze jeden pacient.

Závěr: Reimplantace aortální chlopně představuje komplexní výkon na aortálním kořeni. Pokud je dobře zhodnocena morfologie aortální chlopně, operace správně provedena, metoda je ideální hlavně pro mladší pacienty.

Klíčová slova: Insuficience aortální chlopně - Dilatace sinotubulární junkce - Reimplantace aortální chlopně

Novosad J, Lukeš K, Urban M, et al. Aortic valve reimplantation. Cor Vasa 2010;52:594-596.

Aim: The technique of aortic valve reimplantation (David I) was established in our center in 2005 to be used in the management of patients with aortic root involvement combined with aortic valve insufficiency. The aim of our study was to assess aortic valve function at $1-5$ years post-surgery.

Method: Overall, seven patients (four men, three women) with a mean age of 56.4 years (43-72) were operated. All were diagnosed to have aortic root and ascending aorta dilatation, and aortic valve insufficiency. No impairment of the cusps was demonstrated. Marfan syndrome or ascending aorta dissection were not diagnosed in any of the patients, and the surgery was a scheduled procedure in all cases. Results: Average blood loss was $1155 \pm 548 \mathrm{ml}$, with none of the patients requiring revision for bleeding. Six patients were discharged to receive home care within 6-11 days post-surgery, one female patient after 26 days (due to long-term mechanical ventilation). Echocardiography on follow-up at 12 months revealed aortic valve insufficiency grade $0-1$ in six patients, and grade 2 in one. After five years, severe aortic valve insufficiency was documented in only one patient.

Conclusion: Aortic valve reimplantation is a complex procedure involving the aortic root. The technique is ideal, mainly for younger patients, as long as the aortic valve morphology has been properly assessed and surgery appropriately performed.

Key words: Aortic valve insufficiency - Sinotubular junction dilatation - Aortic valve reimplantation

Adresa: MUDr. Jiří Novosad, Oddělení kardiochirurgie, Kardiocentrum, Nemocnice Podlesí, a. s., Konská 453, 73961 Třinec, Česká republika, e-mail: jiri.novosad@nempodlesi.cz

\section{Úvod}

Reimplantace aortální chlopně (dle Davida I) představuje anatomickou rekonstrukci aortálního kořene. Tato metoda se stala obecně používanou pro záchovné operace aortální chlopně při dilataci aortálního kořene a insuficienci aortální chlopně. Během několika let vznikly různé modifikace reprodukce Valsalvových sinů. Tyto neosiny mají sloužit k normální dynamické funkci aortální chlopně a jejich cílem je snížit mechanické namáhání cípů.

V této práci jsou zahrnuty výsledky od roku 2005, kdy jsme tuto operaci provedli plánovaně u sedmi pacientů.

\section{Metodika a soubor pacientů}

Před vlastním výkonem provádíme kromě echokardiografického a dalších standardních vyšetření i CT angiografické vyšetření (obrázek 1).

Volíme přístup přes střední sternotomii. Aortální kanylu zavádíme do vzestupné aorty nebo přes pravou podklíčkovou tepnu (dle rozsahu dilatace vzestupné aorty), žilní dvoustupňovou kanylu nebo separátní kanylaci dutých žil používáme dle přidružených výkonů. Krystalickou kardioplegii podáváme přes koronární ústí. Aortu odstřihneme asi $5 \mathrm{~mm}$ nad komisurami. Chlopeň a jednotlivé cípy revidu- 


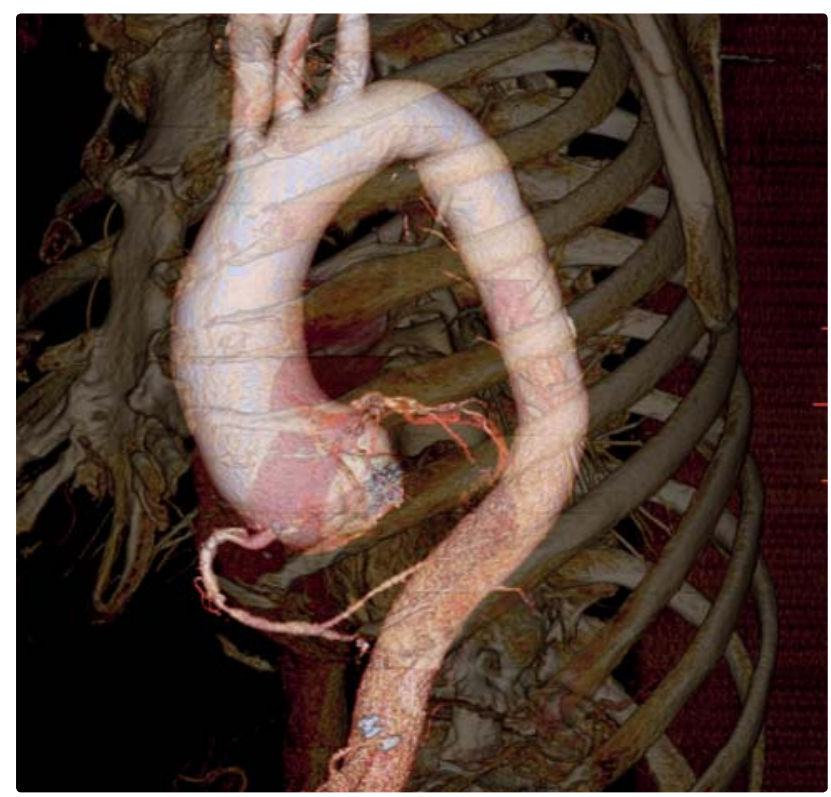

Obrázek 1 CT angiografie hrudní aorty

jeme s cílem určit, zda odpovídají echokardiografickému nálezu a nejsou-li morfologicky změněny, a provádíme kontrolu koaptace.

Pokud tedy rozhodneme o záchovné operaci, aortu odstřihneme s ponecháním 3-5 mm lemu od okraje cípů (obrázek 2), vypreparujeme a odstřihneme koronární tepny $\mathrm{s}$ terčíky. Měŕíme anulus. Podle rozměru anulu $+4 \mathrm{~mm}$ volíme průměr cévní protézy. Následuje preparace výtokového traktu levé komory. Cévní protézu po naměření výšky komisur (obrázek 3) a úpravě fixujeme do výtokového traktu pomocí jednotlivých stehů s podložkami umístěnými lineárně pod anulus. Podložky se nesmějí v žádném případě dotýkat ani omezovat pohyblivost jednotlivých cípů. V další vrstvě všijeme jednotlivé okraje sinů do protézy pokračujícím stehem a také terčíky koronárních tepen (obrázek 4).

Po úpravě distální části vzestupné aorty změříme délku protézy, upravíme a provedeme její suturu do vzestupné aorty (obrázek 5).

U některých pacientů provádíme současně další přidružené výkony dle plánu. U všech pacientů šlo o plánovaný

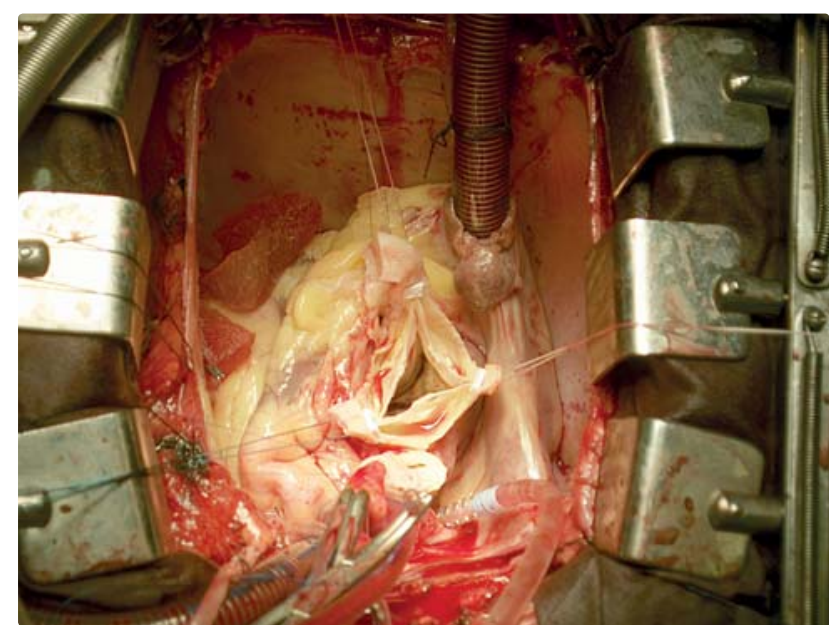

Obrázek 2 Aortální chlopeň s odstřiženou vzestupnou aortou a terčíky koronárních tepen

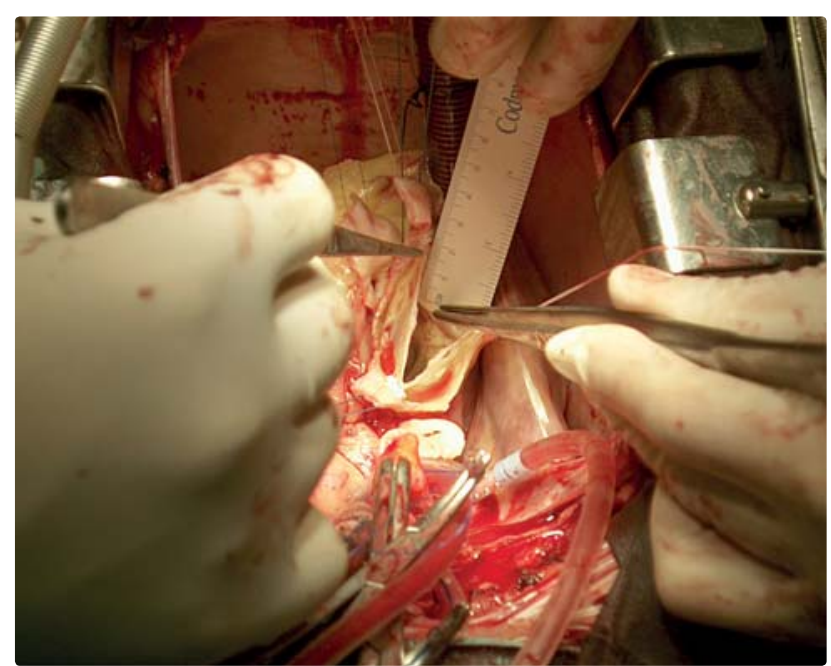

Obrázek 3 Měření výšky komisur

výkon. Žádný pacient neměl disekci vzestupné aorty ani Marfanův syndrom. Všichni pacienti měli trojcípou aortální chlopeň bez prolapsu cípů. $U$ všech byla př́tomna dilatace bulbu a části vzestupné aorty a vždy insuficience aortální chlopně určitého stupně. U pěti pacientů byl použit Valsalva graft (Vascutek Ltd., Renfrewshire, UK), u dvou byla použita cévní protéza (Vascutek Ltd., Renfrewshire, UK). Ve sledované skupině nebyli zahrnuti pacienti s plastikou aortální chlopně ani remodelací aortálního bulbu (podle Yacouba).

Operováno bylo celkem sedm pacientů (čtyři muži, tři ženy) s průměrným věkem 56,4 roku (43-72 let).

Insuficience aortální chlopně byla u tří pacientů 2 . stupně a u čtyř pacientů 3. stupně ze čtyřstupňové škály.

Provedené výkony prezentuje tabulka 1.

Průměrné krevní ztráty dosahovaly $1155 \pm 548 \mathrm{ml}$. Žádný pacient nebyl revidován ani nezemřel. Průměrná doba hospitalizace byla $11,1 \pm 6,6$ dne. $U$ šesti pacientů se nevyskytly žádné závažné pooperační komplikace, byli hospitalizováni 8-11 dní. Jedna pacientka byla hospitalizována 26 dní pro ventilační insuficienci s dlouhodobou umělou plicní ventilací.

Pooperační kontrola se uskutečnila po 12 měsících (viz tabulku 2).

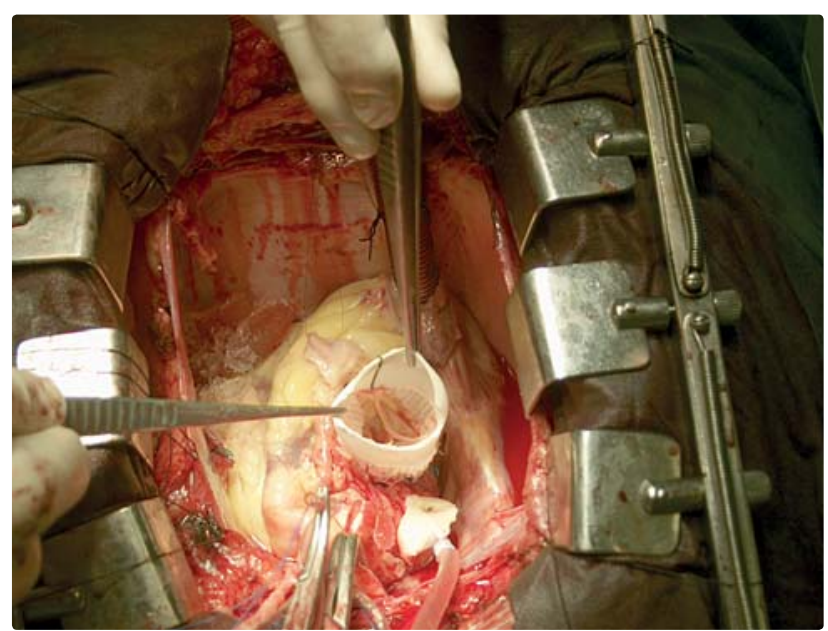

Obrázek 4 Aortální chlopeň všita do Valsalva graftu 


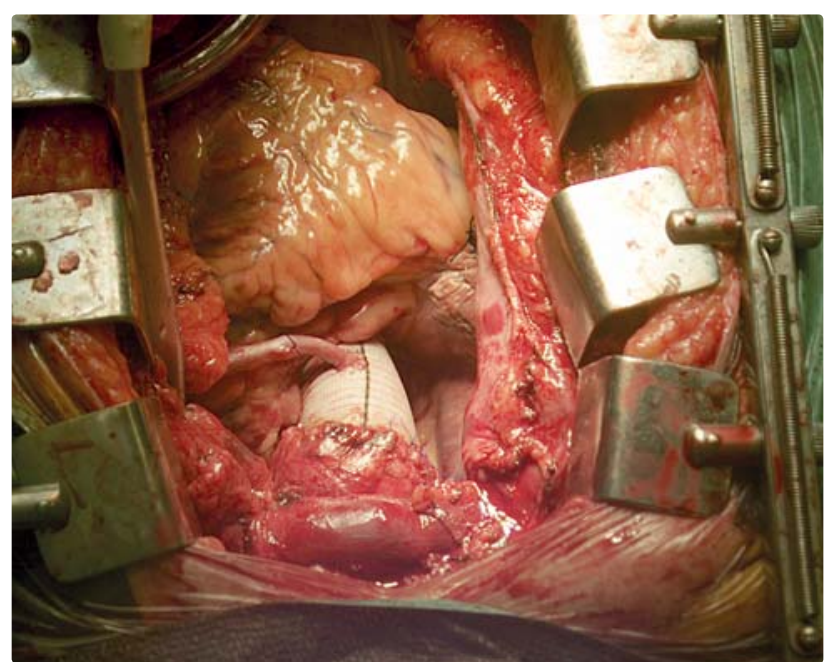

Obrázek 5 Výsledek operace po odpojení z mimotělního oběhu

U jednoho pacienta, u něhož jsme provedli reimplantaci aortální chlopně dle Davida, plastiku mitrální chlopně a aortokoronární bypass, došlo pooperačně $\mathrm{k}$ recidivě aortální insuficience $\mathrm{v}$ důsledku prolapsu jednoho $\mathrm{z}$ cípů. Zpětně hodnoceno sice měl peroperačně stopovou aortální insuficienci, ale nedostatečnou koaptaci cípů. Po pěti letech od primární operace dospěl k reoperaci, kterou však odmítl. Byla mu navržena i transkatetrová implantace aortální chlopně (TAVI), kterou rovněž odmítl.

\section{Diskuse}

Reimplantace aortální chlopně představuje komplexní výkon na kořeni aorty. Dakronová protéza chrání anulus před následnou dilatací. ${ }^{1,2}$ Někteři autoři považují remodelaci aortálního kořene za fyziologičtější pro funkci aortální chlopně, ${ }^{3,4}$ než je reimplantace aortální chlopně. Reimplantaci aortální chlopně indikujeme $\mathrm{v}$ př́padech, $\mathrm{kdy}$ jsou dilatovány dva a více Valsalvových sinů. Pokud je dilatován jeden sinus, obnovujeme ho pomocí dakronové protézy bez reimplantace aortální chlopně. ${ }^{5}$ Metodu jsme zatím nepoužili u pacientů s Marfanovým syndromem, protože jsme se obávali recidivy aortální insuficience vzhledem $\mathrm{k}$ poruše pojiva chlopně. $\mathrm{V}$ posledních letech se metoda užívá s dobrými dlouhodobými výsledky i u těchto pacientů. ${ }^{6-8}$ Metodu zatím nepoužíváme ani v př́padech, kdy prolabuje některý $\mathrm{z}$ cípů a je třeba provádět plastiku těchto cípů. Důležité pro úspěch metody je správné našití aortální chlopně do graftu. ${ }^{9,10}$ Další zásadní věcí je velikost graftu. Př́liš velká protéza může způsobit nedostatečnou koaptaci cípů.

\begin{tabular}{|c|c|c|}
\hline Typ operace & Počet pacientů & $\emptyset \mathrm{ECC} /$ svorka v min \\
\hline $\begin{array}{l}\text { Reimplantace } \\
\text { aortální chlopně }\end{array}$ & 4 & $147,2 \pm 12 / 116,5 \pm 3,9$ \\
\hline$+\mathrm{MVP}+2 \times \mathrm{CABG}$ & 1 & \\
\hline$+\mathrm{MVP}$ & 1 & \\
\hline$+1 \times C A B G$ & 1 & $217,3 \pm 44,2 / 154,3 \pm 25,6$ \\
\hline
\end{tabular}

\section{Tabulka 2 Stupeň aortální insuficience po 12 měsících}

\begin{tabular}{cl}
\hline NYHA $0-I$ & 5 pacientů \\
$\|$ & 2 pacienti \\
\hline $\begin{array}{cl}\text { Echokardiografie: stupeň aortální insuficience } \\
0-1\end{array}$ & 6 pacientů \\
3 & 1 pacient \\
\hline
\end{tabular}

Naproti tomu přiliš malá protéza vede $\mathrm{k}$ častějšímu selhání chlopně. ${ }^{11}$ Někteří autoři cíleně zmenšují aortální anulus. ${ }^{3}$ Další otázkou je použití typu cévní protézy. Někteří chirurgové peroperačně konstruují neosiny z větší a menší cévní protézy, jiní používají Valsalva graft již s preformovanými siny. ${ }^{8,12}$ Obě metody mají své zastánce i odpưrce. Na našem pracovišti v současné době používáme Valsalva graft.

\section{Závěr}

Reimplantace aortální chlopně není v našich podmínkách jistě každodenním výkonem. Zásadní je předoperační zhodnocení morfologie aortální chlopně. Pokud se tedy $\mathrm{k}$ takovému výkonu rozhodneme, je třeba, aby operaci prováděl zkušený chirurg. Dalším kritickým bodem je zvolení velikosti cévní protézy. Pokud je operace správně indikována, dobře provedena, je ideálním řešením hlavně pro mladší pacienty s aneurysmatem kořene aorty.

\section{Literatura}

1. David TE, Ivanov J, Armstrong S, et al. Aortic valve-sparing operations in patients with aneurysms of the aortic root or ascending aorta. Ann Thorac Surg 2002;74:S1758-S1761.

2. David TE, Feindel CM, Webb GD, et al. Aortic valve preservation in patients with aortic root aneurysm: results of the reimplantation technique. Ann Thorac Surg 2007;83:S732-S735.

3. Svensson LG, Cooper M, Batizy LH, Nowicki ER. Simplified David reimplantation with reduction of annular size and creation of artificial sinuses. Ann Thorac Surg 2010;89:1443-1447.

4. Aicher $D$, Langer $F$, Lausberg $H$, et al. Aortic root remodeling: ten-year experience with 274 patients. J Thorac Cardiovasc Surg 2007;134:909-915.

5. David TE. Remodeling of the aortic root and preservation of the native aortic valve. Op Tech Cardiac Thorac Surg 1996;1:44-56.

6. de Oliveira NC, DavidTE, Ivanov J, et al. Results of surgery for aortic root aneurysm in patients with Marfan syndrome. Thorac Cardiovasc Surg 2003;125:789-796.

7. David TE, Armstrong S, Maganti M, et al. Long-term results of aortic valve-sparing operations in patients with Marfan syndrome. J Thorac Cardiovasc Surg 2009;138:859-864.

8. Settepani F, Szeto WY, Pacini D, et al. Reimplantation valve-sparing aortic root replacement in Marfan syndrome using the Valsalva conduit: an intercontinental multicenter study. Ann Thorac Surg 2007;83:S769-S773.

9. Pethig K, Milz A, Hagl C, et al. Aortic valve reimplantation in ascending aortic aneurysm: risk factors for early valve failure. Ann Thorac Surg 2002;73:29-33.

10. Kallenbach K, Baraki H, Khaladj N, et al. Aortic valve-sparing operation in Marfan syndrome:What do we know after a decade? Ann Thorac Surg 2007;83:S764-S768.

11. Burkhart HM, Zehr KJ, Schaff HV, et al. Valve-preserving aortic root reconstruction: a comparison of techniques. J Heart Valve Dis 2003;12:62-67.

12. De Paulis R, De Matteis GM, Nardi $P$, et al. Opening and closing characteristics of the aortic valve after valve-sparing procedures using a new aortic root conduit. Ann Thorac Surg 2001;72:487-494.

Došlo do redakce 20. 8. 2010

Prijato 20. 9. 2010 